\title{
Petrology of Intrusive Bodies of Azizabad-Tinamo Area in the South of Songour, Iran
}

\author{
Siavash Gholizadeh1, Mohammad-Ali Arian1", Mahammad-Reza Jafari', Abdollah Yazdi² \\ ${ }^{1}$ Department of Geology, Faculty of Sciences, North Tehran Branch, Islamic Azad University, Tehran, Iran \\ ${ }^{2}$ Department of Geology, Kahnooj Branch, Islamic Azad University, Kerman, Iran \\ Email: ^maa1361@yahoo.com
}

How to cite this paper: Gholizadeh, S., Arian, M.-A., Jafari, M.-R. and Yazdi, A. (2016) Petrology of Intrusive Bodies of Azizabad-Tinamo Area in the South of Songour, Iran. Open Journal of Geology, 6, 1567-1579.

http://dx.doi.org/10.4236/ojg.2016.612111

Received: October 31, 2016

Accepted: December 25, 2016

Published: December 28, 2016

Copyright $\odot 2016$ by authors and Scientific Research Publishing Inc. This work is licensed under the Creative Commons Attribution International License (CC BY 4.0).

http://creativecommons.org/licenses/by/4.0/

\begin{abstract}
In terms of structural divisions of the Iran's earth crust, the studied area is considered as a part of the Sanandaj-Sirjan structural zone and Zagros Thrust. In this area, there are two gabbroic-dioritic and syenitic igneous intrusive bodies. The host rocks of these intrusive bodies are upper Cretaceous limestones and formed by contactmetamorphism at the contact zone between hornfels rocks and skarn. Field and geochemical datasets represent that all various rocks within these intrusive bodies have been originated from the same magma. The process of fractional crystallization and probably a small amount of contamination and assimilation has also played a role in the evolution of parent magma. Generally, these magmas are sub-alkaline and lie in themagmatic range of tholeiitic and calc-alkaline series. Samples investigated are metaluminous and peralkaline.
\end{abstract}

\section{Keywords}

Syeniteintrusive Bodies, Gabbro-Diorite and Granite, Sub-Alkaline, Metaluminous

\section{Introduction}

The studied area is located in the 1:100,000-scale geological map of Songour and the west of Iran (Figure 1).

The some parts of the stratigraphic units in the studied area belong to SanandajSirjan structural zone and other parts are related to Zagros Thrust Zone, which marked by the large fractures and multiple thrusts, and resulted to structural complexity of the area (Figure 2). This area, by the following of geological events in the area, was under the influence of different deformation phases whether orogenic or epeirogenic, the emplacement of intrusive bodies, metemorphism, and other geological events. 

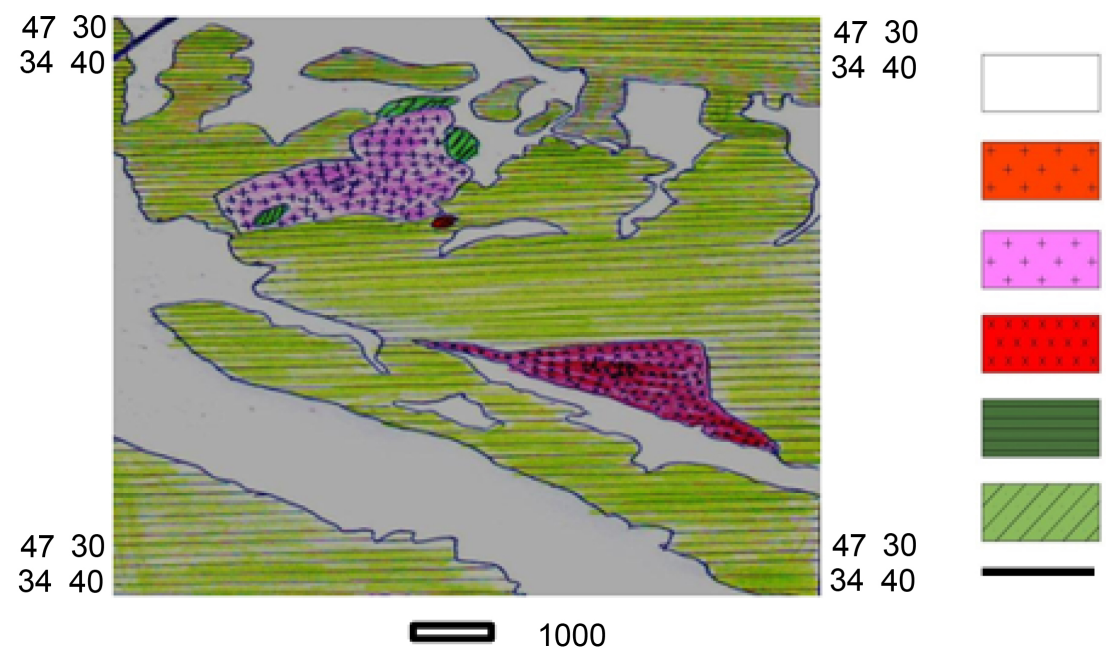

Alluvium

$\mathrm{N}$

Granite

\$

Syenite

Gabbro

Sedimentary Rocks

Metamorphic Rocks

Figure 1. Map of the study population [1].

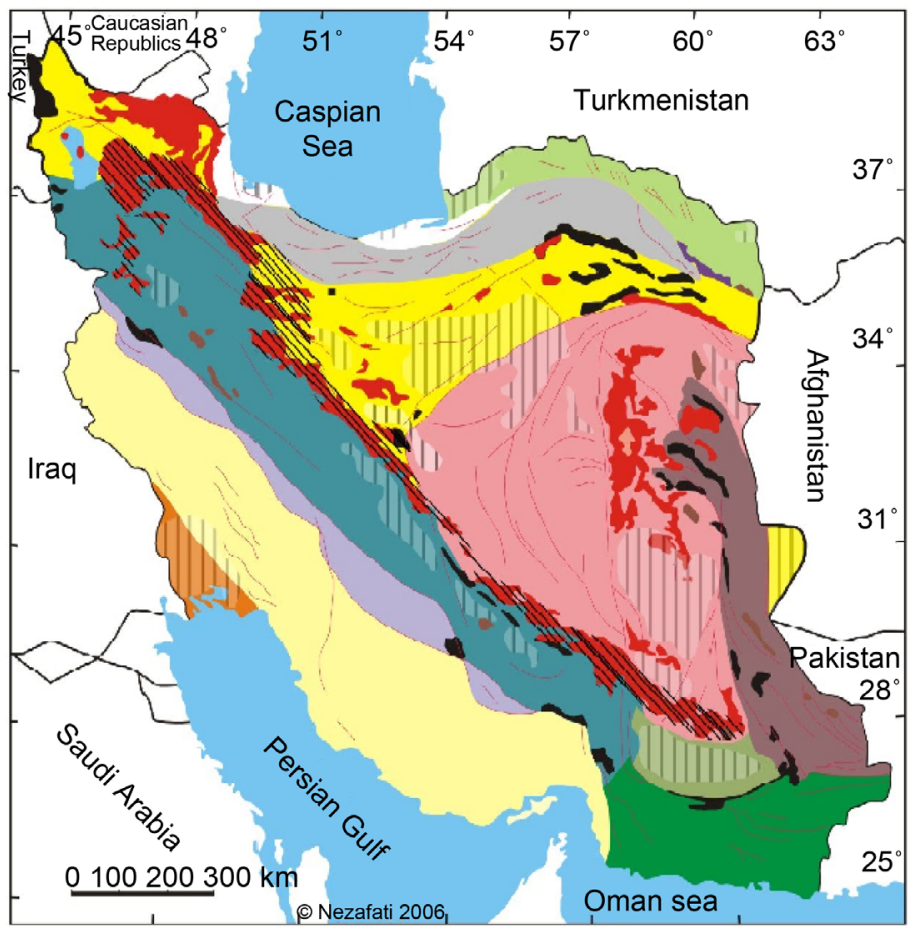

\begin{tabular}{|c|c|c|c|}
\hline Khuzestan plain & Alborz Mountains & $\begin{array}{l}\text { Makran } \\
\text { (Fore arc basin) }\end{array}$ & Volcanic rocks \\
\hline Zagros fold belf & Central Domain & Eastern Iran & Paratethys basin \\
\hline $\begin{array}{l}\text { Zagros Thrust } \\
\text { (Disputable) }\end{array}$ & $\begin{array}{l}\text { Central Iran Micro-continent } \\
\text { (Lut Block) }\end{array}$ & $\begin{array}{l}\text { Ophiolite } \\
\text { (Neo-Tethys oceanic crust) }\end{array}$ & Depressions \\
\hline Sanandaj-Sirjan zone & Kopeh Dagh & $\begin{array}{l}\text { Ophiolite } \\
\text { (Paleo-Tethys oceanic crust) }\end{array}$ & Faults \\
\hline
\end{tabular}

Figure 2. Structural and sedimentary zones of Iran [2]. 
Given that the Sanandaj-Sirjan zone having NW-SE trending is parallel to the Zagros Thrust Faults, and by considering that this zone has severely affected by these faults activities in during different geological periods after the Cretaceous, as a result, in the area investigated the severe effects of tectonic activities could be well observed due to the proximity to the Main Zagros Fault. Among these features, it can be referred to thrust nappes, the presence of thrust faults with Quaternary age, regional metamorphism and intrusion of gabbroic to syenitic bodied and a small amount of granite.

The rocks cropping out in the studied area belong to the Mesozoic and Cenozoic era and the oldest of them is related to the Upper Cretaceous. These intrusions are Tertiary in age and have been injected in the upper Eocene-Oligocene due to the Pyrenean orogenic phase.

This study aims to determine the formation mechanism of gabbros, syenites and granites, discover the genetic relationship among the intrusive bodies of the region, and determine the change and frequency of major and trace elements in the rocks of the region.

\section{Geological and Tectonic Setting}

The area studied with coordinates of $47^{\circ} 30^{\prime}$ to $47^{\circ} 40^{\prime}$ east longitude and $34^{\circ} 30^{\prime}$ to $34^{\circ} 40^{\prime}$ north latitude is located in the southern part of 1:100,000 geological sheet of Songour and mountainous area with rough topography, and covers an area of over 280 square kilometers. The area of the intrusions outcrops in this region is about 25 square kilometers (Figures 3-5). Many faults in this area are of thrust or high angle reverse type, but there are less normal and strike-slip faults. One of the characteristics of the faults in the area is their seismicity so that until now several major earthquakes have been occurred in the region and caused the destruction of houses. Faults in the area are the valley-building. This means that the valleys and waterways have been created in trend of some faults due to slip, displacement and crushing caused by faulting and subsequent erosion.

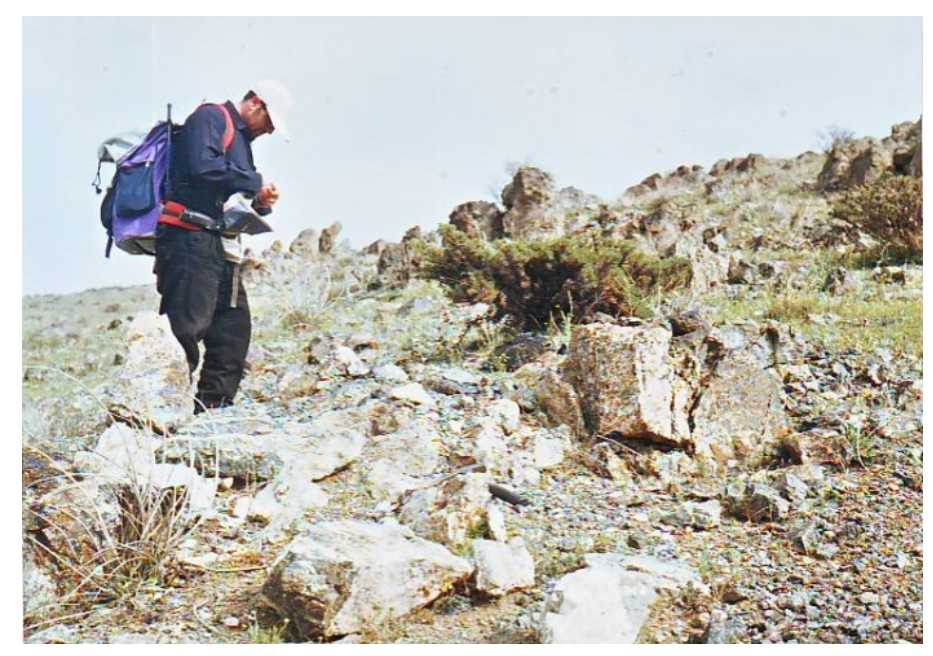

Figure 3. Gabbroic rocks of the area. 


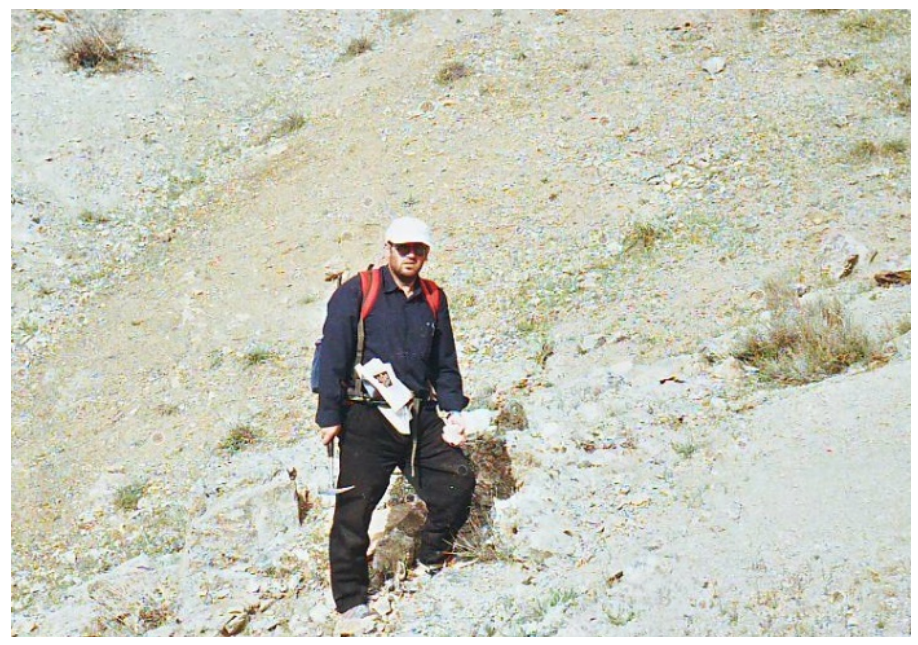

Figure 4. An outcrop of syenite rock.

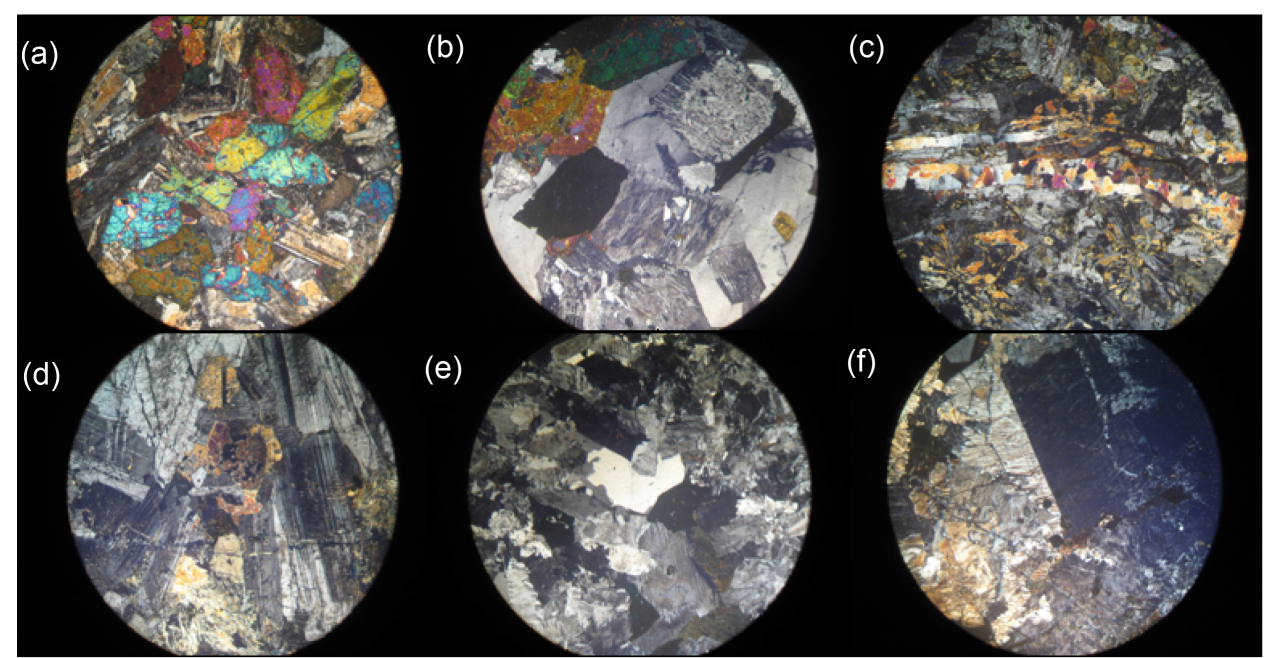

Figure 5. Selected microscopic images of rock groups studied (in crosspolarizedlight, XPL) (a) Hornblend (b) Augite (c) Quartz recrystallization (d) Polysynthetic Plagioclase (e) Quartz and (f) Perthite Orthose (XPL. 40×).

In the late Eocene and probably during the Pyrenean orogeny [3], governing compressive forces on the region along with other geological processes have caused to intrusion and emplacement of intrusive bodies in the studied area. Under the influence of the same orogenic phase, the contact metamorphism as well as metasomatism resulting from emplacement of intrusion have been occurred and caused the formation of skarn units in Deh Asyab and the position to form in the marble limestones in the studied area as well. This phase also resulted in folding and possibly faulting of the older units.

\section{Petrology}

According to 19 different type of rocks using ICP-MS and alkaline fusion technique the analysis (Table 1 and Table 2) and the geochemical diagrams of rocks nomenclature [4] and [5], most samples in the studied area would be fallen in the range of the gabbro, 
Table 1. Chemical analysis of intrusive pluton in south of Songour.

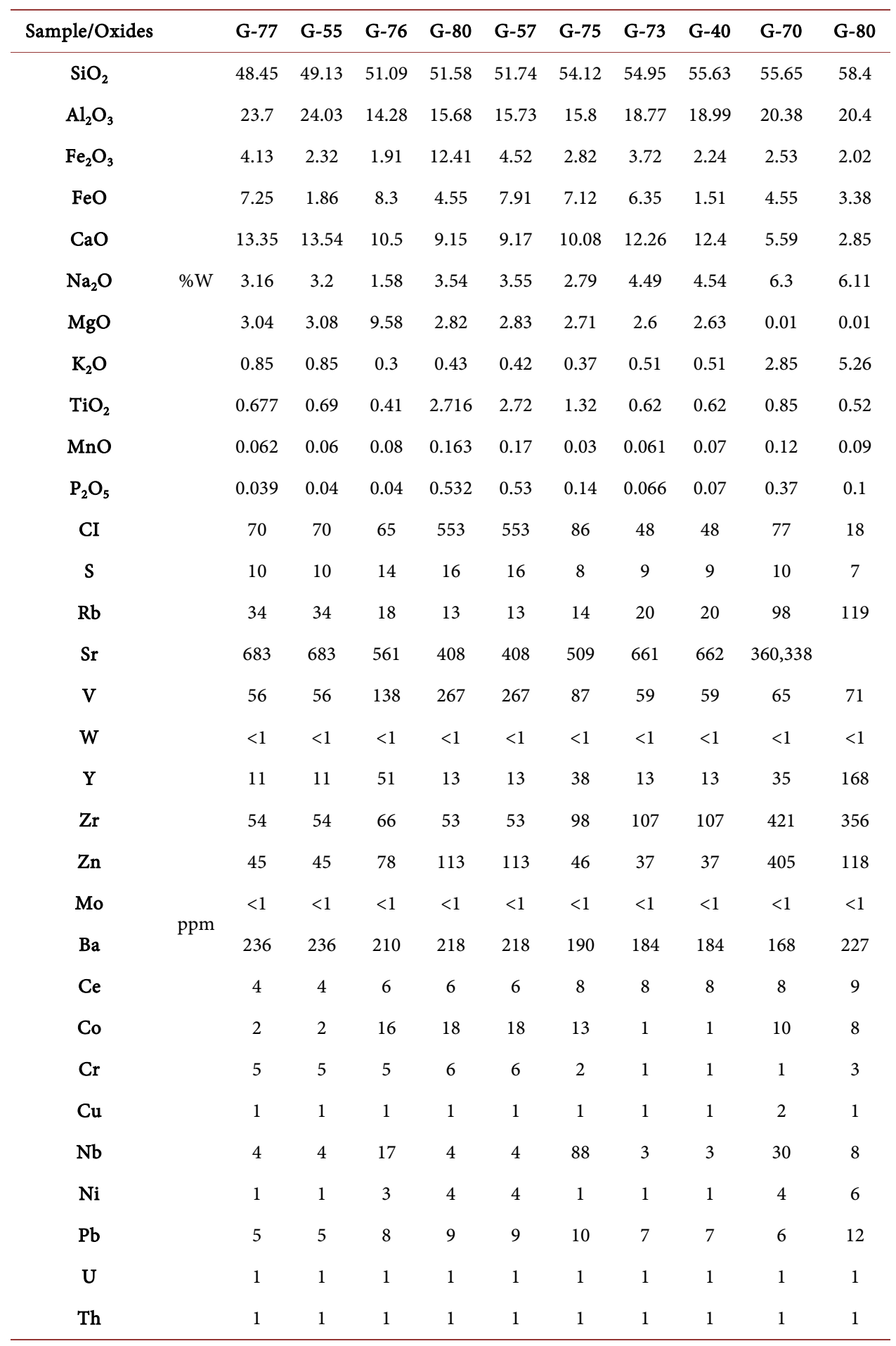

gabbro-diorite, diorite, monzonite, syenite, quartz monzonite and granite (Figure 6 and Figure 7).

In the diagram AFM [6], the samples would be fallen in both of tholeiitic and calcalkaline range. In the diagrams $\mathrm{Na}_{2} \mathrm{O} / \mathrm{SiO}_{2}[6]$, and $\mathrm{K}_{2} \mathrm{O} / \mathrm{SiO}_{2}$ [7], most samples are 
Table 2. Chemical analysis of intrusive pluton in south of Songour.

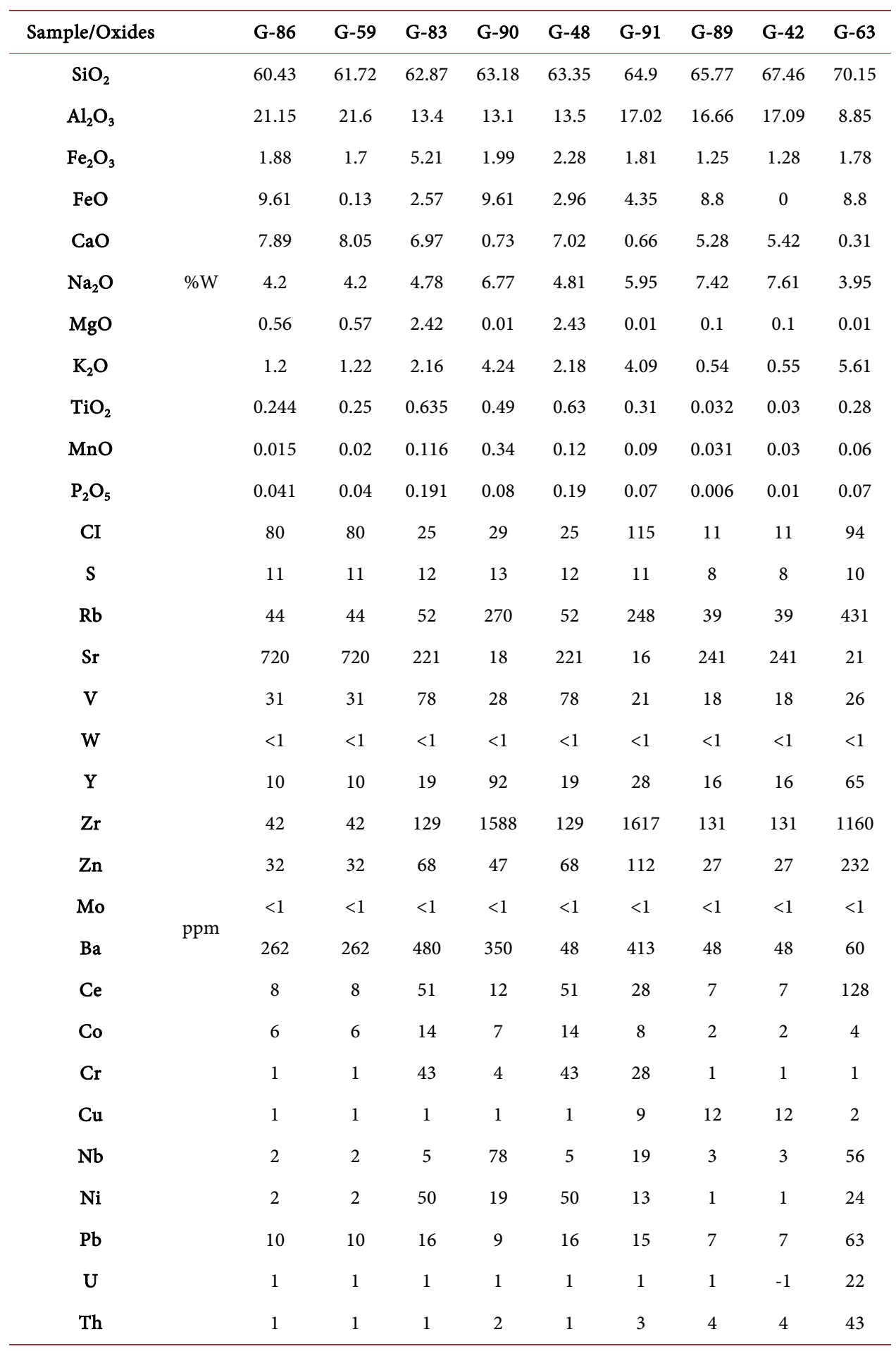

plotted in alkaline and sub-alkaline basalt fields. These diagrams represent an almost disorder linear trend for samples in the area studied. These disorders could be resulted from the crustal contamination of some intrusive magmas and increase in the amount of $\mathrm{K}_{2} \mathrm{O}$ within them, which of course does not reject the same origin of all magmas of 


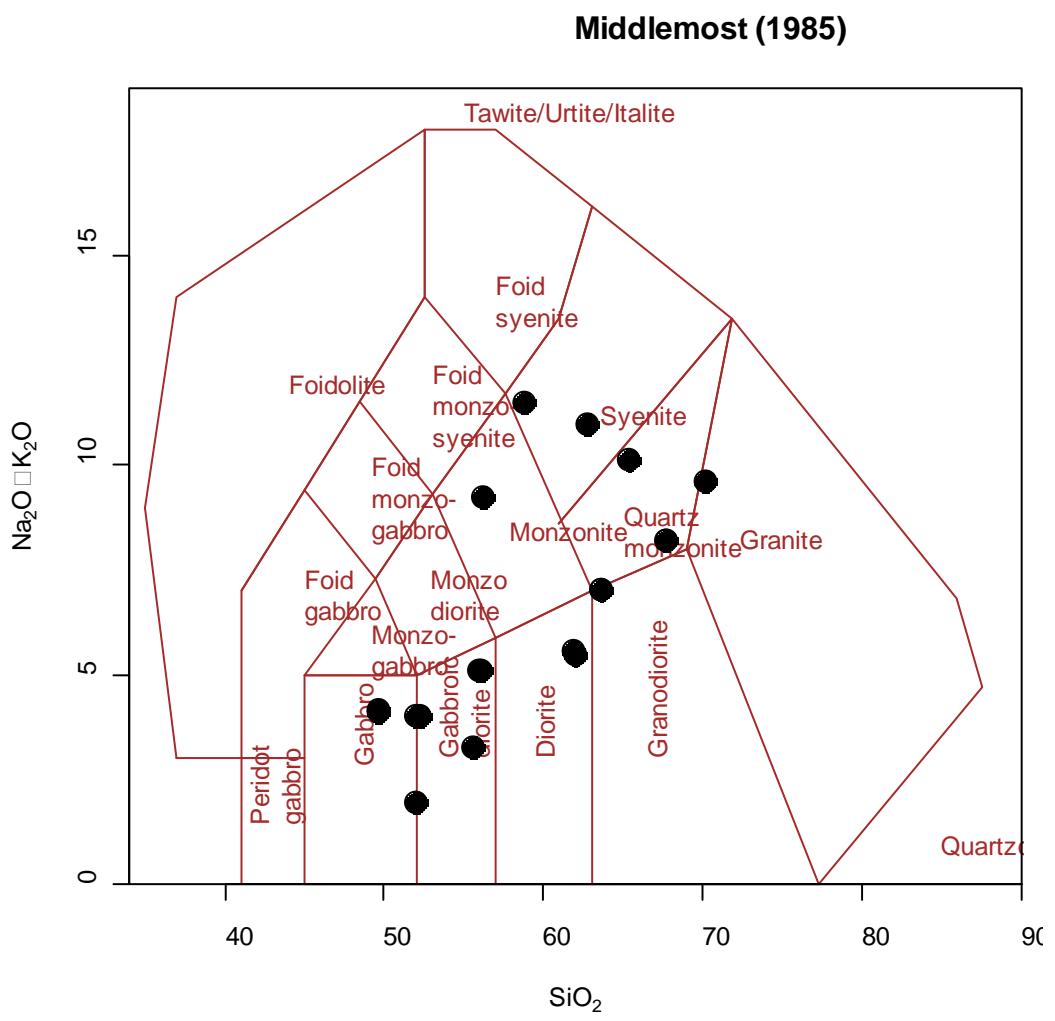

Figure 6. Determination of intrusive rocks type diagram [4].

TAS (Middlemost 1994)

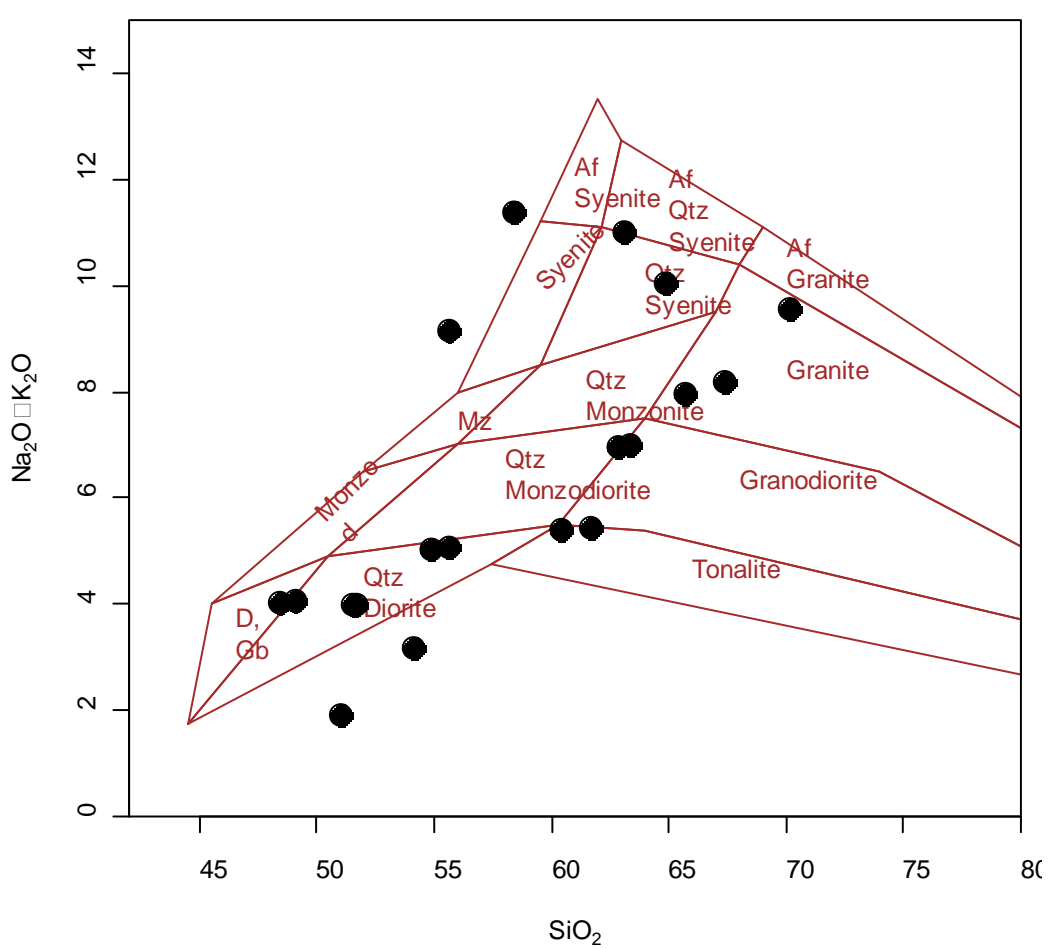

Figure 7. Determination of intrusive rocks type diagram [5]. 
the area (Figures 8-10).

Based on the aluminum saturation diagram [8], 18 samples are in metaluminous and peralkaline fields. One example is in field of peraluminous, indicting the igneous origin of all the samples (Figure 11).

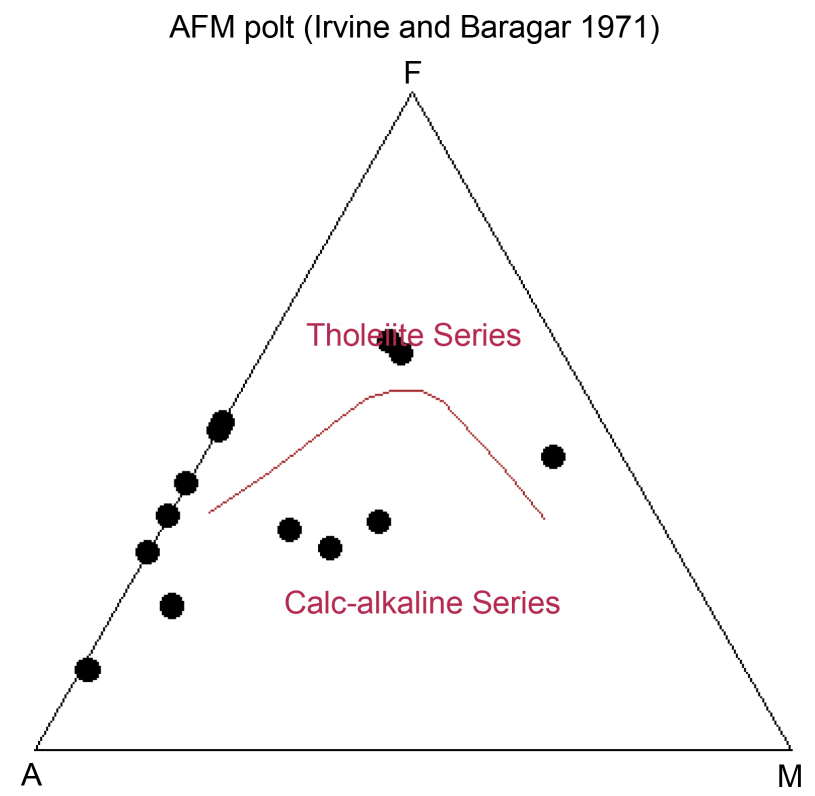

Figure 8. Determination of magmatic series diagram using the major element oxides data [6].

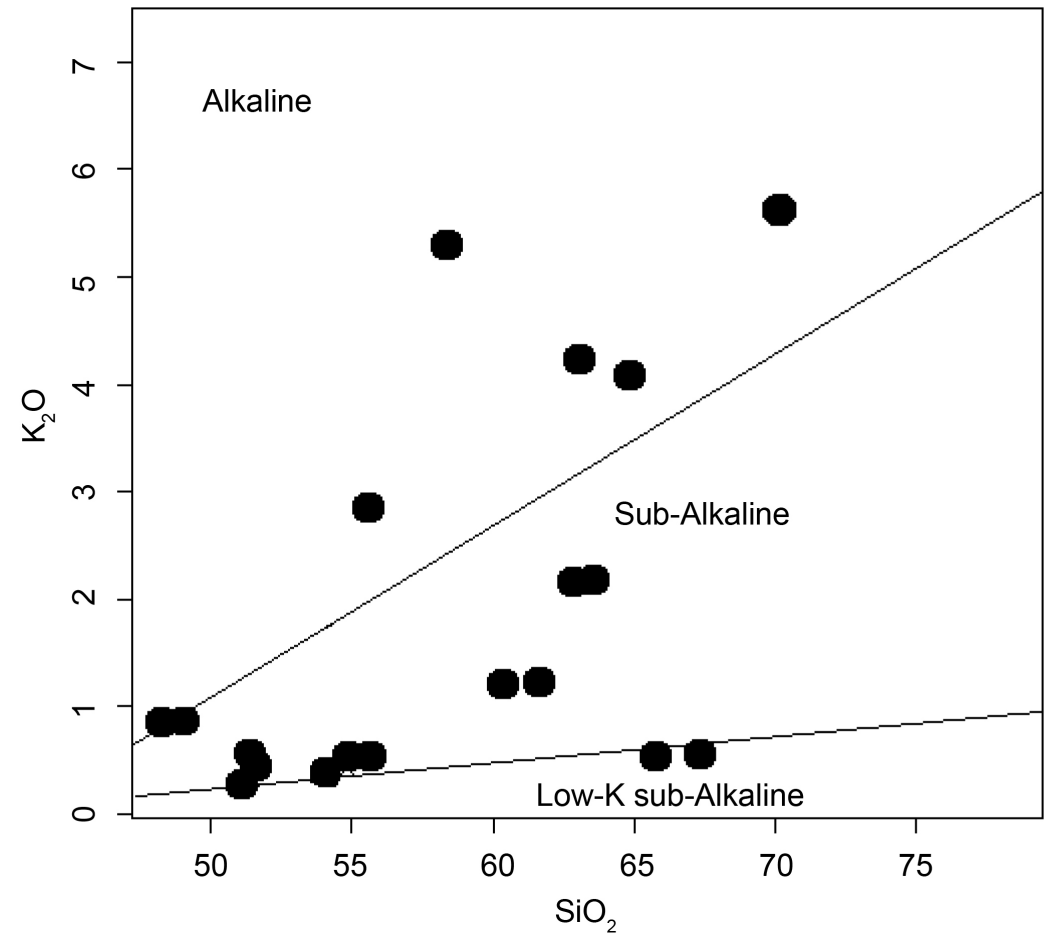

Figure 9. $\mathrm{Na}_{2} \mathrm{O} / \mathrm{SiO}_{2}$ diagram to determine magmatic series [6]. 


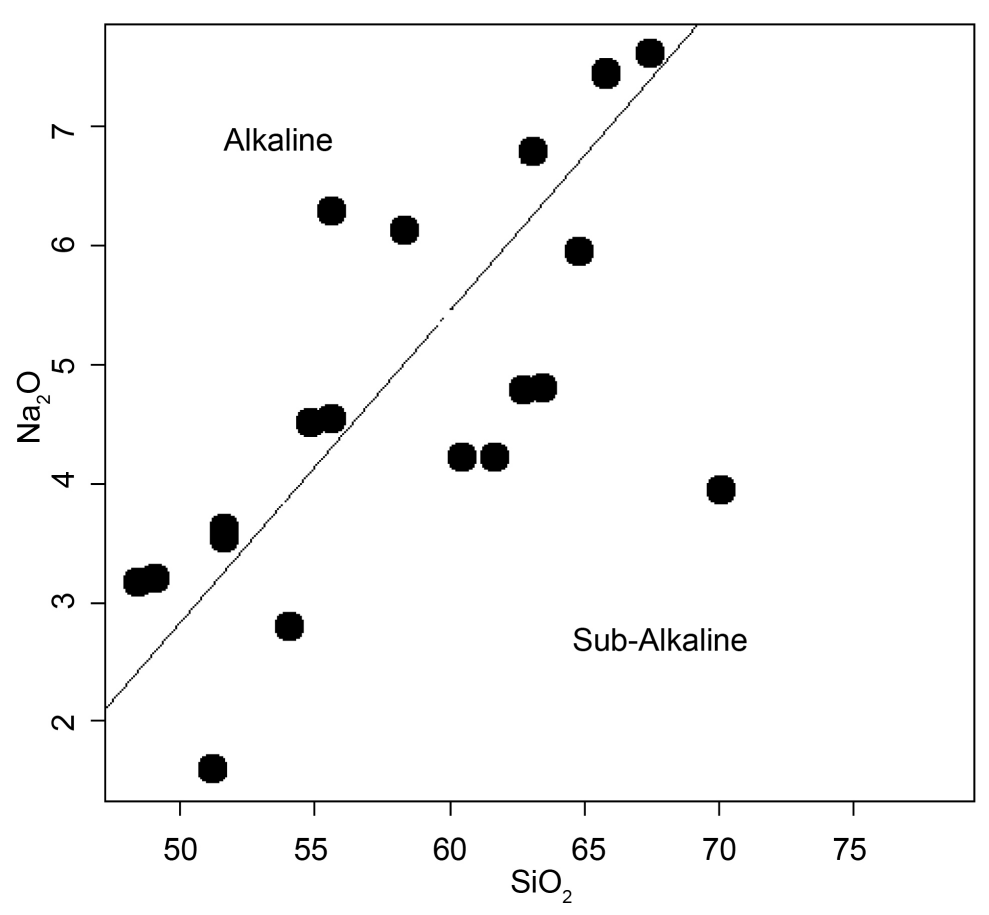

Figure 10. $\mathrm{K}_{2} \mathrm{O} / \mathrm{SiO}_{2}$ diagram to determine magmatic series [7].

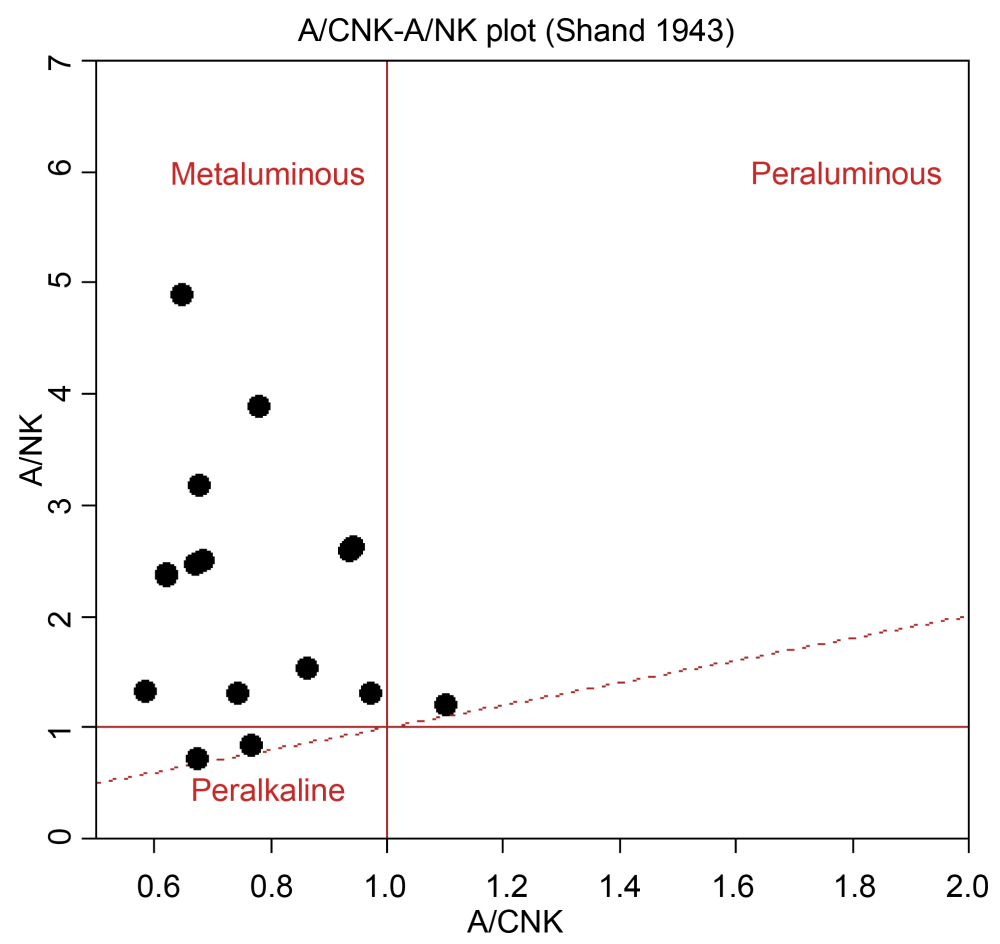

Figure 11. Aluminum saturation diagram to determine magmatic series [8].

Based on the major element oxides vs. $\mathrm{SiO}_{2}$ [9], the oxides $\mathrm{Al}_{2} \mathrm{O}_{3}, \mathrm{MgO}, \mathrm{CaO}, \mathrm{TiO}_{2}$, $\mathrm{P}_{2} \mathrm{O}_{5}$ and $\mathrm{FeO}$ decrease with increasing silica content and being more acidic of rocks, and $\mathrm{K}_{2} \mathrm{O} \mathrm{Na}{ }_{2} \mathrm{O}$ oxides show increasing (Figure 12). 

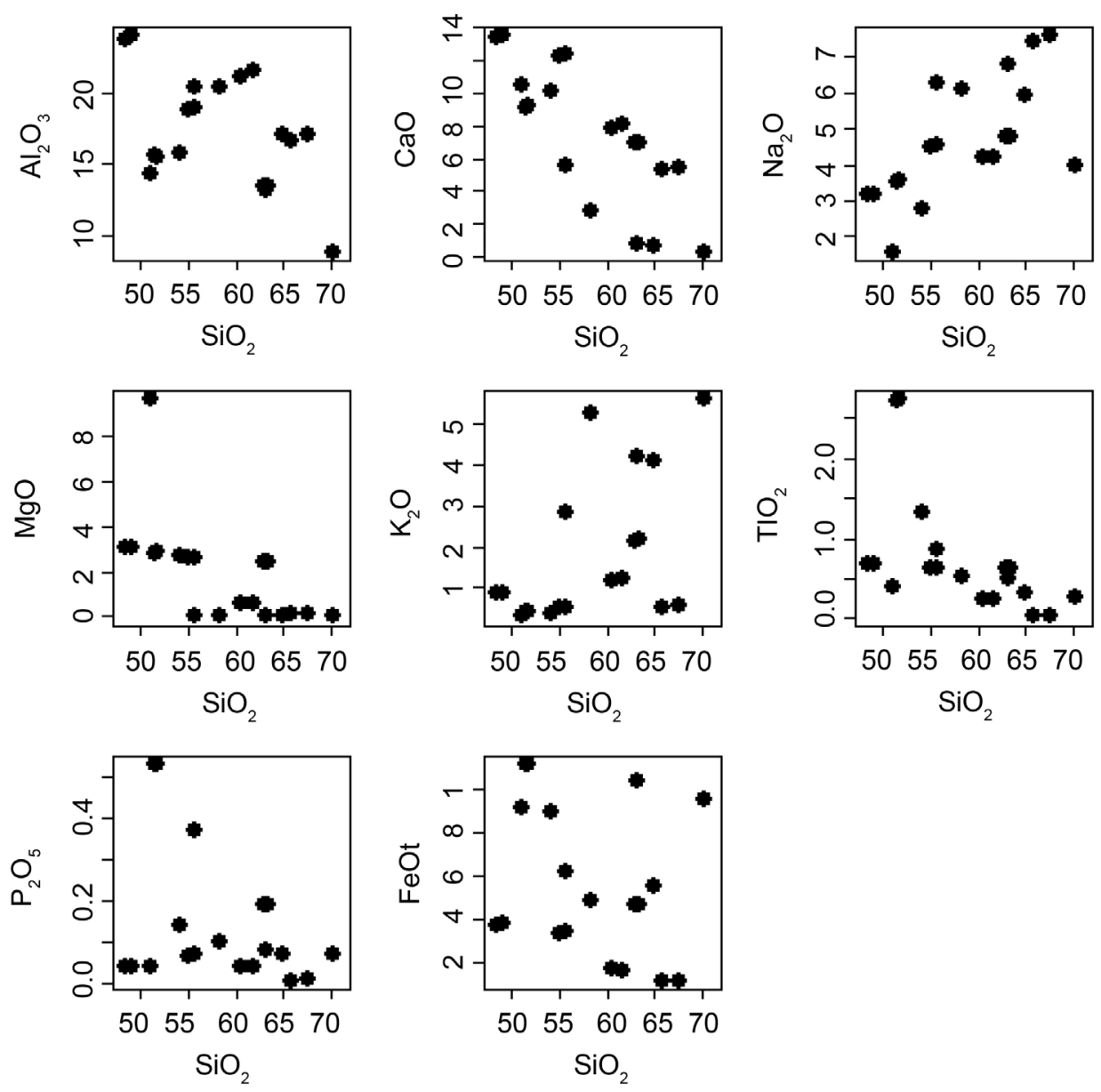

Figure 12. Variation plots of the major element oxides vs. silica [9].

Based on the magnesium and calcium oxidesvs. silica diagram, the two almost regular trends it could be inferenced so that the basic to intermediate samples and the intermediate and acidic samples would be fallen follow each other, which this relationship between the two series of basicand intermediate magmas, on the one hand, and on the other hand between intermediate and acidic magmas can be deduced, and this would be confirmed by field geological studies so that the basic to intermediate rocks (gabbros and diorites) present with each other and the intermediate to acidic rocks (monzonite, syenite, quartz syenite and granite) could also be found near each other, and a distinct gradual variation among them can be understandable.

On the diagram $\mathrm{Na}_{2} \mathrm{O}$ vs. $\mathrm{SiO}_{2}$, the two trends can be observed. The increasing $\mathrm{Na} 2 \mathrm{O}$ from basic rocks to high-silica acidic rocks (about to 63\%) and decreasing trend from rocks with more than $66 \%$ silica toward more acidic rocks, which could be attributed to $\mathrm{Na}_{2} \mathrm{O}$ depletion in magma and its use in the formation of sodium-bearing feldspars.

According to the rare earth elements vs. $\mathrm{SiO}_{2}$ diagrams, the elements rubidium $(\mathrm{Rb})$, yttrium (Y), zirconium ( $\mathrm{Zr}$ ), selenium (Se), nickel ( $\mathrm{Ni})$, thorium (Th) and niobium $(\mathrm{Nb})$ increase with increasing $\mathrm{SiO}_{2}$, and the elements strontium ( $\mathrm{Sr}$ ), barium (Ba), chromium (Cr) and cobalt (Co) show decreasing trend (Figure 13). 


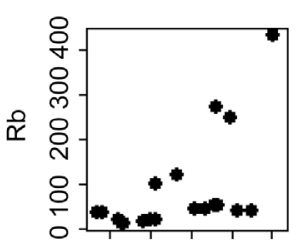

5055606570

$\mathrm{SiO}_{2}$
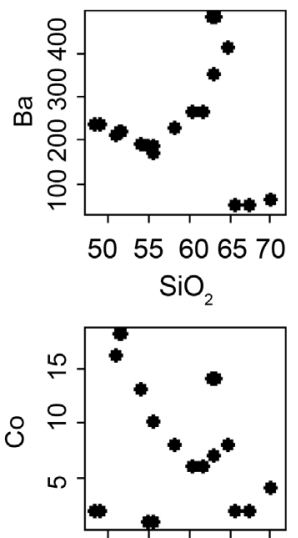

5055606570 $\mathrm{SiO}_{2}$

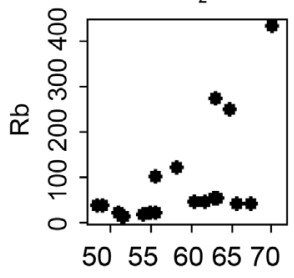

$\mathrm{SiO}_{2}$
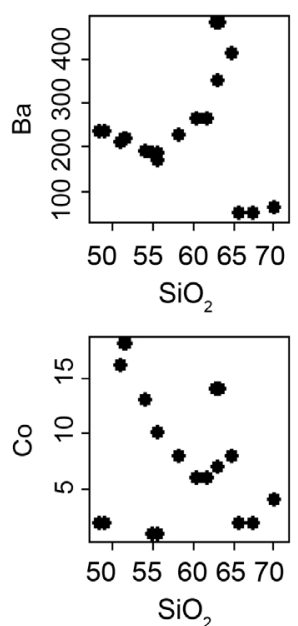

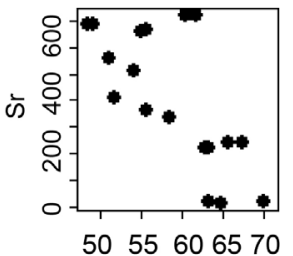

$\mathrm{SiO}_{2}$
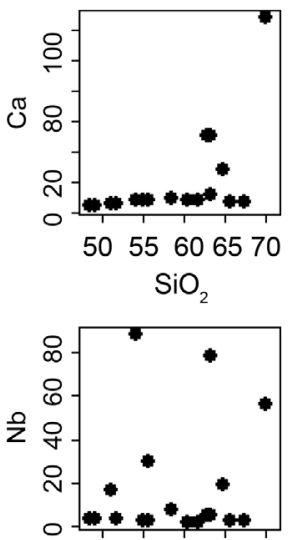

5055606570 $\mathrm{SiO}_{2}$
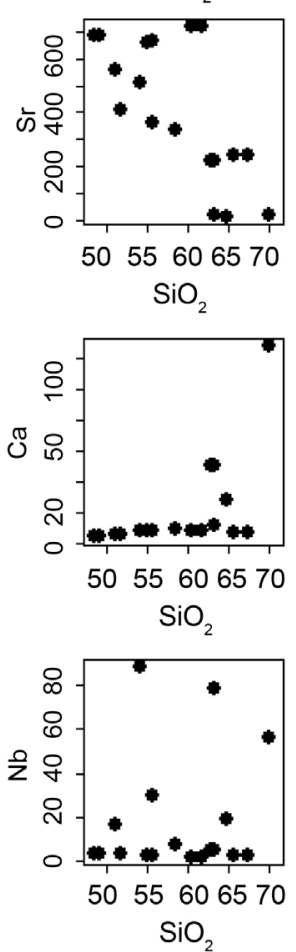

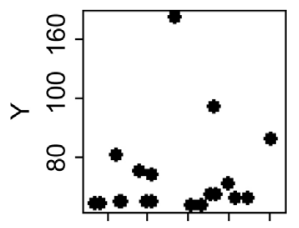

5055606570

$\mathrm{SiO}_{2}$
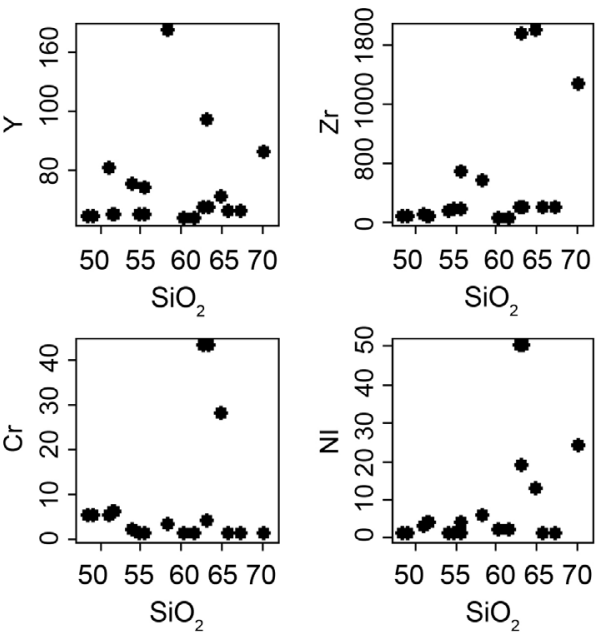

5055606570

$\mathrm{SiO}_{2}$
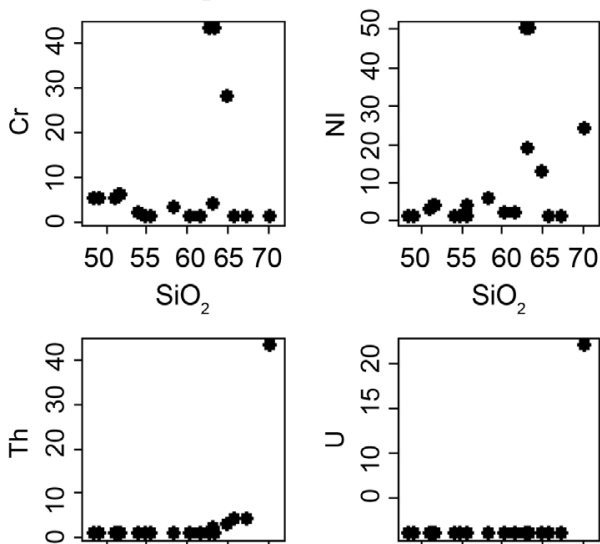

5055606570

$\mathrm{SiO}_{2}$

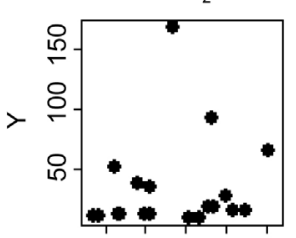

5055606570 $\mathrm{SiO}_{2}$
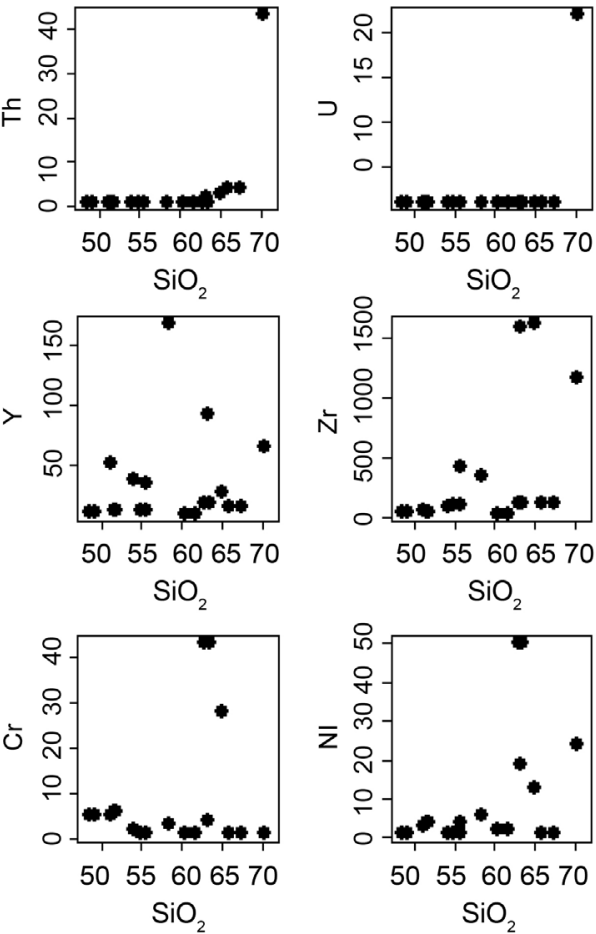

5055606570

$\mathrm{SiO}_{2}$

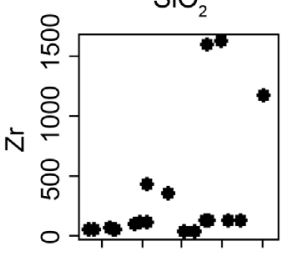

5055606570 $\mathrm{SiO}_{2}$

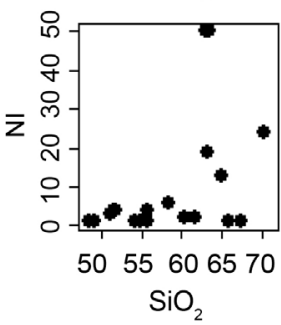

Figure 13. Variation plots of the trace elements vs. silica [9].

The value of $\mathrm{Rb}$ increases with increasing $\mathrm{SiO}_{2}$ in the magma, due to consumption of $\mathrm{Rb}$ alkali feldspar's structure. A dispersion could be observed on the diagram $\mathrm{Ba}$ vs. $\mathrm{SiO}_{2}$, suggesting the process of partial melting, assimilation and magmatic contamination in the region. Yttrium $(\mathrm{Y})$ is one of the rare earth elements, which concentrates in 
acidic terms particularly pegmatites and display a systematic increasing trend from basic to acidic rocks. This systematic increasing could be indicating the same source of magmas in the studied area. Dispersion could be seen on the variation plot of Co vs. $\mathrm{SiO}_{2}$, of course, higher Co content would be consumed within initial Mg-bearing minerals especially olivine. The scattered points on the diagrams are another evidence for the existence of the assimilation and magma mixing or only one of these two processes. Cr would be removed from the magma as chromite mineral in the early stages of crystallization. Also, $\mathrm{Cr}$ would be accumulated in pyroxenes, especially the ultra-basic pyroxenes. Based on the diagram $\mathrm{Cr}$ vs. $\mathrm{SiO}_{2}, \mathrm{Cr}$ has more concentrated in four samples (normal) and two syenite samples (abnormal). This abnormal concentration could be resulted from the assimilation and magma mixing processes, of course, at the smallscale, because has created anomaly only in two samples.

\section{Conclusion}

According to petrographic and mineralogical studies of thin sections of rocks collected from the studied area, the intrusive igneous rocks in the region from basic to acidic terms include gabbro, gabbro-diorite, diorite, quartz-bearing syenodiorite, syenite, quartz-bearing syenite and granite, which gabbroic and syenitic rocks contain the largest volume in the area studied. The most studied samples are saturated with silica and in terms of the aluminum saturation are peralkaline and metaluminous. Generally, almost all the lithological and geochemical diagrams indicate a single source for these samples. It appears that the basaltic magma originated from the mantle, has intruded into the crust by weakness point of the crust namely the Zagros Main Thrust located in the south part of intrusive bodies. This magma has slightly fractionated in situ during solidification and this resulted in the formation of rocks from gabbro to syenite and granite, which of course, from the time of stopping until the magma has been cooled and solidified, the main basaltic intrusive (confirmed by large volume of gabbros) was able to contaminate with the crust and led to increase in some elements, such as potassium. In the Eocene and Oligocene magmatism of the Zagros Thrust and SanandajSirjan zones including the studied area, the cause of high compression by tensile and opening forces is acceptable.

\section{References}

[1] Eshraghi, S.A., Jafarian, M.B. and Eghlimi, B. (1996) Geological Square Map of Songour, Scale 1:100,000. Geological Survey and Mineral Exploration of Iran.

[2] Eftekharnejad, J. (1980) The Extension of Structural and Sedimentary Zones of Iran. 40.

[3] Braud, J. and Bellon, H. (1975) Donneesnouvellessur Ir domain metamorphique du zagros (Zone de Sanandaj-Sirjan) au niveau de Kermanshah-Hamadam (Iran): Nature, age et interpretation des series metamorphiques et des intrusions: Evolution structural.

[4] Middlemost, E.A.K. (1985) Magmas and Magmatic Rocks. Longman, London.

[5] Middlemost, E.A.K. (1994) Naming Materials in the Magma/Igneous Rock System. EarthScience Reviews, 37, 215-224. 
[6] Irvine, T.N. and Baragar, W.R.A. (1971) A Guide to the Chemical Classification of the Common Volcanic Rocks. Canadian Journal of Earth Sciences, 8, 523-548.

[7] Middlemost, E.A.K. (1975) The Basaltclan. Earth Sciences Review, 11, 337-364.

[8] Shand, S.J. (1943) Eruptive Rocks. Their Genesis Composition. Classification, and Their Relation to Ore-Deposits with a Chapter on Meteorite. John Wiley \& Sons, New York.

[9] Harker, A. (1909) The Natural History of Igneous Rocks. Methuen \& Co., London, 344 p.

Submit or recommend next manuscript to SCIRP and we will provide best service for you:

Accepting pre-submission inquiries through Email, Facebook, LinkedIn, Twitter, etc.

A wide selection of journals (inclusive of 9 subjects, more than 200 journals)

Providing 24-hour high-quality service

User-friendly online submission system

Fair and swift peer-review system

Efficient typesetting and proofreading procedure

Display of the result of downloads and visits, as well as the number of cited articles

Maximum dissemination of your research work

Submit your manuscript at: http://papersubmission.scirp.org/

Or contact ojg@scirp.org 